This is an electronic reprint of the original article. This reprint may differ from the original in pagination and typographic detail.

Author(s): Shaikh, Aijaz A.; Karjaluoto, Heikki

Title: $\quad$ The effects of mobile banking application user satisfaction and system usage on bankcustomer relationships

Year: $\quad 2016$

Version:

Please cite the original version:

Shaikh, A. A., \& Karjaluoto, H. (2016). The effects of mobile banking application user satisfaction and system usage on bank-customer relationships. In Academic MindTrek'16 : Proceedings of the 20th International Academic MindTrek Conference (pp. 177-183). Association for Computing Machinery (ACM).

https://doi.org/10.1145/2994310.2994330

All material supplied via JYX is protected by copyright and other intellectual property rights, and duplication or sale of all or part of any of the repository collections is not permitted, except that material may be duplicated by you for your research use or educational purposes in electronic or print form. You must obtain permission for any other use. Electronic or print copies may not be offered, whether for sale or otherwise to anyone who is not an authorised user. 


\section{The Effects of Mobile Banking Application User Satisfaction and System Usage on Bank-Customer Relationships}

\author{
Aijaz A. Shaikh \\ Jyväskylä University School of Business and \\ Economics \\ P.O. Box 35, FI-40014 \\ University of Jyväskylä, Finland \\ +358468911363 \\ aijaz.a.shaikh@jyu.fi
}

\author{
Heikki Karjaluoto \\ Jyväskylä University School of Business and \\ Economics \\ P.O. Box 35, Fl-40014 \\ University of Jyväskylä, Finland \\ +358405767814 \\ heikki.karjaluoto@jyu.fi
}

\begin{abstract}
This study examines mobile banking (m-banking) application usage in Finland by linking it with customer-bank relationship development. Specifically, we examine how usage is related to relationship commitment, overall satisfaction, intention to recommend the bank and future intentions to remain with the bank. A survey was used to collect data from experienced $\mathrm{m}$ banking application users. In total, 273 valid responses were received. The results support the hypotheses and reveal that user satisfaction with m-banking application usage has a strong positive association with usage of $\mathrm{m}$-banking applications. Usage, in turn, was positively related to all examined bank-customer relationship related variables. The results have both theoretical and practical implications for m-banking usage and its effects on bank-customer relationships.
\end{abstract}

\section{CCS Concepts}

- Information systems $\rightarrow$ Information systems applications

\section{Keywords}

Mobile banking; Continuous usage; User satisfaction, System usage; Relationship commitment; Behavioral intention; Overall satisfaction; Intention to recommend.

\section{INTRODUCTION}

The emergence of mobile technology and its increasing usage for banking purposes has heralded new opportunities for the banking sector. New mobile-based technology makes it convenient for consumers to use financial services anywhere, provided mobile communication is available [40]. If consumers value this mobility, it is possible that those who presently make transactions online via a personal computer may move to transacting via a mobile device. After all, the so-called 'typical customer' no longer exists; consumers now prefer to obtain services from various channels rather than a single one [15] for the purposes of convenience.

Permission to make digital or hard copies of all or part of this work for personal or classroom use is granted without fee provided that copies are not made or distributed for profit or commercial advantage and that copies bear this notice and the full citation on the first page. Copyrights for components of this work owned by others than ACM must be honored. Abstracting with credit is permitted. To copy otherwise, or republish, to post on servers or to redistribute to lists, requires prior specific permission and/or a fee.

Request permissions from permissions@acm.org. AcademicMindtrek'16, October 17-18, 2016, Tampere, Finland

(C) 2016 ACM. ISBN 978-1-4503-4367-1/16/10_.\$15.00 DOI: http://dx.doi.org/10.1145/2994310.2994330
The continuous usage of information systems such as m-banking is often described as a mature research area in the relationship marketing and information systems (IS) literature [33]. Specifically, the m-banking literature has so far concentrated on examining intentions to use m-banking and often relies on samples of individuals that do not have prior experience of using the service. Moreover, research on the outcomes of m-banking is completely lacking. In addition, information systems applications have become extremely important in the last few years, but little research exists on m-banking application usage behavior [3].In this paper, we aim to fill this notable gap in the literature by studying a post-adoption scenario, specifically focused on how mbanking usage and user satisfaction are related to the development of bank-customer relationships.

This study therefore extends the literature by investigating how customers' actual experiences of using m-banking applications shape their relationships with their banks. We examined four customer relationship outcomes, namely consumer relationship commitment, overall satisfaction, intention to recommend the bank, and behavioral intention to remain a customer of the bank. We hypothesized that user satisfaction with m-banking applications is positively associated with application/system usage, which in turn positively affects the bank-customer relationship in terms of commitment, overall satisfaction, intention to recommend, and behavioral intention to remain a customer of the bank. We control the four outcomes for the effects of gender, age, income, and duration of the banking relationship. The study specifically focuses on m-banking application usage on cell phones or tablets by consumers living in Finland. The reason for this is that m-banking is a widely used banking platform in Finland.

The remaining sections of the paper are organized as follows: Section 2 presents the study's theoretical background including a brief overview of the state of m-banking in Finland; Section 3 presents the conceptual model and hypotheses; Section 4 describes and discusses the research methodology; Section 5 presents the data analysis and study results; and Section 6 discusses the study's limitations, contributions and recommendations for future research.

\section{THEORETICAL BACKGROUND}

Popular digital banking channels include online banking, automated teller machines (ATMs), Interactive voice response (IVR) systems, point-of-sale (POS), telephone and the recently introduced $\mathrm{m}$-banking, branchless banking and social media banking platforms. There is still some confusion between the 
terms 'm-banking' and 'branchless banking.' Here, m-banking refers to the facilitation of consumer access to banking information and the ability to conduct transactions on cell phones and tablets. M-banking is becoming very popular in developed markets. Branchless banking, also known as correspondent or agent banking, is primarily intended for unbanked and underbanked segments of society and therefore has proved to be one of the most promising strategies for offering banking and financial services to developing and emerging markets. Compared to traditional (or branch) banking and online banking, the main advantage of m-banking is ubiquity [45], i.e. with the help of mobile networks, devices and terminals, users can conduct banking transactions anytime and anywhere using any portable device.

Previous research in the area of IS and consumer behavior has primarily focused on initial adoption or acceptance of a technology and has identified continuous usage intention as a valuable research stream. Here, 'IS continuous usage,' 'IS continuance,' and 'IS continuance intention' [25] refer to usage behavior after a 'system' or 'product' has been adopted by the consumer. Moreover, the ultimate viability and the success of an IS depends on the consumer's continued usage [17].

Finland occupies a significant position in developing and deploying advanced wireless and digital banking infrastructure, which allows different consumers real-time access to managing their financial portfolio using a variety of options, including but not limited to telephones, the internet and mobile. Online banking services were first introduced in Finland in the mid-1990s [18], followed by m-banking services in 1996 [16]. According to [37], more than 85 percent of the adult population (up to 75 years of age) in Finland has signed up for online banking services. With respect to mobile devices, approximately 60 percent of users own a smartphone with internet access, and 32 percent (approximately one-third) of Finnish households (approx. 5.4 million) own at least one tablet [37]. Despite this promising adoption and usage of portable devices, desktop computers and laptops have remained the most preferred devices for paying bills; just seven percent of the adult population use smart phones or tablets as their primary devices for paying bills [9]. A few market reports [10], however, have predicted exponential growth in m-banking usage in Finland.

\section{CONCEPTUAL MODEL AND HYPOTHESES}

The conceptual model guiding this study is illustrated in Figure 1, which shows the hypothesized relationships between the study constructs.

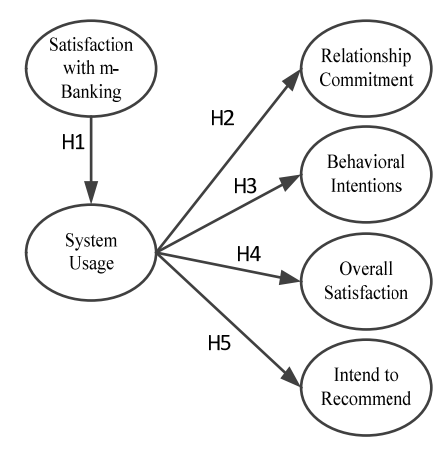

Figure 1. Research Model

Based on the literature review, the authors developed five hypotheses regarding the interrelationships between m-banking application user satisfaction, usage, relationship commitment, behavioral intention to remain a customer of the bank, overall satisfaction, and intention to recommend the bank.

System or application usage, in general, has been considered a direct function of behavioral intention, which leads to increased satisfaction. System usage is defined as 'either the amount of effort expended interacting with an information system or, less frequently, as the number of reports or other information products generated by the information system per unit time' [41, p. 33]. On the other hand, user satisfaction in the context of IT job performance was initially defined by [27] as a positive emotional state resulting from the appraisal of one's job. From a marketing perspective, satisfaction depends largely on a product or service's performance [2]. Continuous usage and user satisfaction with a system have been widely examined in prior research [4] and used as surrogate measures for IS such as m-banking success. Reference [4] explained that a significant positive relationship exists between system usage and user satisfaction. Reference [22] had previously asserted that system utilization leads to user satisfaction and that both factors are positively related. Thus, it was hypothesized that:

H1: User satisfaction with an m-banking application is positively associated with the usage of that m-banking application.

Against the backdrop of expanding digital banking portfolios, where new banking channels such as social network banking and branchless banking have recently been added, examining the relationship between m-banking usage and bank-customer relationship development provides a new angle for $\mathrm{m}$-banking research.

In its simplest form, relationship commitment is defined as an 'enduring desire to maintain a valued relationship' [11, p.71]. Prior research [e.g., 19; 14] suggests that satisfaction alone may not adequately ensure long-term customer commitment to a single service provider. Instead, it may be necessary to look beyond satisfaction toward other variables that strengthen retention in order to ensure economically viable long-term relationships.

The present study examines the relationship between system usage and customers' commitment to their bank through postadoption usage behavior. Reference [39] has argued that when an information technology is properly used it can facilitate relationship commitment between the customer and the company. In addition, [34] found that relationship commitment with a bank increases when using m-banking services. It was therefore hypothesized that:

H2: Usage of an m-banking application is positively associated with relationship commitment to the bank.

Future behavioral intention is a causal predictor of behavior that mediates the influence of various beliefs and external variables such as individual and system characteristics on an individual's behavior [42]. Behavioral intention refers to the degree to which a person has formulated conscious plans to perform or not to perform some specified future behavior [44]. As argued by [30], past behavior contributes to intentions, and behavior is guided by intentions. Reference [12] argued that attitude influences future behavior when it is easy to retrieve from memory and is stable over time. In addition, expressing an attitude repeatedly and having direct experience with the attitude's object, product or service influence the attitude-behavior relationship by inducing higher attitude accessibility. Due to its inevitability, behavioral intention has been used extensively in prior research as a predictor of system use after acceptance [e.g., 42]. However, no research to 
date has specifically tested the relationship between system usage and behavioral intention in the context of m-banking application use. Therefore, we wanted to test this relationship, hypothesizing that:

H3: Usage of an m-banking application is positively associated with behavioral intention to remain a customer of the bank.

Overall satisfaction (also referred as cumulative satisfaction or integrated satisfaction) is considered distinct from 'satisfaction.' For example, customer satisfaction (also referred to as transactional satisfaction) provides shallow feedback and support to a company and a marginal increase in profit. Overall satisfaction, on the other hand, is an overall evaluation based on the total purchase and consumption experience of a good or service over time [11, p.7]. Previous research has analyzed overall satisfaction with online channel services and concluded that customers' overall satisfaction with a service provider is determined by the service quality provided through the online channel, as well as through the traditional channel [28]. Specifically with regard to continuous intention to use mobile internet services, prior studies have established that user satisfaction consistently results in high continuance usage intention [26] and that continuance usage intention of mobile internet users will grow stronger as their overall satisfaction with the mobile internet service increases [20]. It was therefore hypothesized that:

H4: Usage of an m-banking application is positively associated with overall satisfaction with the bank.

The advent of new technologies, products and services has intensified the interaction between and among various individuals and groups. Factors influencing users' intention to recommend $\mathrm{m}$ banking and payment technologies have not yet been comprehensively assessed [29]. It is widely believed that the intention to recommend (commonly known as word of mouth; WOM) produces benefits for a firm and WOM has significant implications for a wide range of management activities such as customer acquisition and retention, product development and quality assurance [36]; [8].

WOM involves 'the sharing of information about a product or a service between a consumer and a friend, colleague or other acquaintance' [35, p156]. Reference [23] claimed that the influence of WOM is stronger on consumers who have purchased services (such as m-banking services) than on consumers who have purchased products; this is because services are experience goods for which quality is easier to ascertain. Prior research has found a strong relationship between continuous usage or continuous usage intention and WOM. For instance, [35] and [5] analyzed the factors contributing to continuance intention to use m-banking services and social media and found that electronic WOM played a significant role in creating satisfaction, which ultimately produce continuous usage intention. Based on these findings, it is clear that IS continuance usage and WOM are positively related. Analyzing e-services usage behavior in the context of online travel services, [23] found that continuance usage intention and WOM are positively associated. It was therefore hypothesized that:

H5: Usage of an m-banking application is positively associated with the intention to recommend the bank to others.

\section{RESEARCH METHODOLOGY}

This study investigates the continuous usage of an m-banking application on a cell phone or tablet by bank account holders in Finland who have used the m-banking application over a six- month period. A market research firm's online panel was used to collect data from the results of a pretested survey instrument.

A three-step procedure was adopted to develop and validate the survey questionnaire. During the first step, the latent variables (see Figure 1) were measured with multiple items on a sevenpoint Likert scale, ranging from 1 (strongly disagree) to 7 (strongly agree) with two exceptions. In measuring intention to recommend, we used the Net Promoter Score (NPS) scale, ranging from 0 (not at all likely) to 10 (very likely). System usage was measured with two items: 'Please estimate how much of your banking (as a percentage) is conducted via an m-banking application' (measured on a ten-point scale ranging from $0-10$ percent to 100 percent) and 'Recalling the last ten times you logged into wireless banking services, how many times did this involve an m-banking application?' (Measured on a ten-point scale anchored from $1=$ once to $10=$ ten times).

During the second stage, the survey items were translated from English to Finnish by a researcher who was a native Finnish speaker. To ensure consistency, the items were back-translated into English by a different researcher. During the third stage, the survey instrument was pretested with a group of students at a local university. The underlying objective of this pretest was to check the psychometric properties of the scales [38]. Information collected from the pretest study was used to improve the wording of a few items and enhance the clarity and readability of the questions.

All questionnaire items were adapted from previous studies to preserve content validity [38]. User satisfaction with $\mathrm{m}$-banking application usage was measured with four items adapted from a study by [21].The two items for measuring system usage were adopted from [7]. Overall satisfaction, commitment to the bank and behavioral intentions were measured using the scales from [11]. Intention to recommend was measured with a single item adapted from [31]. The indicators used in the survey are presented in the appendix. A few modifications were made to the items to fit the specific context of this research (i.e., continuous usage of $\mathrm{m}$ banking technology). The research model also included four control variables for gender, age, income, and duration of relationship with the bank. The control variables were measured using single-item scales.

Data was collected by the market research firm's online panel over a two-week period. The survey link was sent to a panel of 5,000 consumers. A total of 392 respondents completed the survey questionnaire. After scrutinizing the collected questionnaires and removing those who were not experienced $\mathrm{m}$ banking users, we obtained a total of 273 valid responses. Because this research addresses continuous m-banking usage intention, we postulated that direct experience would enable users to convey more information about the m-banking application, and, as argued by [1], experienced users are assumed to provide more reliable and realistic evaluations.

To assess nonresponse bias, the responses of the first 25 percent of respondents were compared to the responses of the last 25 percent of respondents. There were no significant differences between the responses of the two groups at the $p<0.05$ level. Thus, it is unlikely that nonresponse bias affected our results.

Potential common method bias was examined using the test proposed by [24], which adds a common method factor to the model and compares the strength of the item factor loadings between the common method factor and the original factors. In this test, the average variance explained by the original indicators was 0.826 , whereas the average method-based variance was only 
0.046 (ratio about 18:1). These results indicate that common method bias is not a serious concern in our study.

More than half of the 273 respondents ( 53.5 percent) were female. Nearly 80 percent were between the ages of 26 to 64 years, and only 12.1 percent were between the ages of 18 to 25 years. A total of 8.5 percent were equal to or over 65 years. Sixty-two percent of the participants had an individual monthly gross income of 2,001 to 6,000 Euros. The demographic characteristics of the sample are presented in Table 1.

Table 1. Demographic Characteristics of Respondents and their M-Banking Usage

\begin{tabular}{|c|c|c|c|}
\hline $\begin{array}{l}\text { Demographic } \\
\text { Characteristics }\end{array}$ & Category & $\begin{array}{l}\text { Frequency } \\
\text { (N) }\end{array}$ & Percent \\
\hline \multirow[t]{2}{*}{ Gender } & Female & 146 & 53.5 \\
\hline & Male & 127 & 46.5 \\
\hline \multirow[t]{5}{*}{ Age } & $18-25$ & 33 & 12.1 \\
\hline & $26-34$ & 68 & 24.9 \\
\hline & $35-49$ & 79 & 28.9 \\
\hline & $50-64$ & 70 & 25.6 \\
\hline & $\geq 65$ & 23 & 8.50 \\
\hline \multirow{11}{*}{$\begin{array}{l}\text { Monthly Income (in } \\
\text { Euros) }\end{array}$} & $\leq 1,000$ & 14 & 5.1 \\
\hline & $1,001-2,000$ & 22 & 8.1 \\
\hline & $2,001-3,000$ & 57 & 20.9 \\
\hline & $3,001-4,000$ & 37 & 13.6 \\
\hline & $4,001-5,000$ & 38 & 13.9 \\
\hline & $5,001-6,000$ & 37 & 13.6 \\
\hline & $6,001-7,000$ & 23 & 8.4 \\
\hline & $7,001-8,000$ & 14 & 5.1 \\
\hline & $8,001-9,000$ & 12 & 4.4 \\
\hline & $9,001-10 \mathrm{~K}$ & 6 & 2.2 \\
\hline & $>10 \mathrm{~K}$ & 13 & 4.7 \\
\hline \multirow[t]{2}{*}{ System usage } & $\leq 10 \%$ & 50 & 18.3 \\
\hline & $11-20 \%$ & 25 & 9.2 \\
\hline \multirow{8}{*}{$\begin{array}{l}\text { Please estimate how } \\
\text { much of your } \\
\text { banking (as a } \\
\text { percentage) is } \\
\text { conducted via an m- } \\
\text { banking application }\end{array}$} & $21-30 \%$ & 29 & 10.6 \\
\hline & $31-40 \%$ & 21 & 7.7 \\
\hline & $41-50 \%$ & 19 & 7.0 \\
\hline & $51-60 \%$ & 13 & 4.8 \\
\hline & $61-70 \%$ & 16 & 5.9 \\
\hline & $71-80 \%$ & 25 & 9.2 \\
\hline & $81-90 \%$ & 50 & 18.3 \\
\hline & $91-100 \%$ & 25 & 9.2 \\
\hline \multirow{10}{*}{$\begin{array}{l}\text { Recalling the last ten } \\
\text { times you logged } \\
\text { into wireless } \\
\text { banking services, } \\
\text { how many times did } \\
\text { this involve an m- } \\
\text { banking application? }\end{array}$} & 1 time & 48 & 17.6 \\
\hline & 2 times & 29 & 10.6 \\
\hline & 3 times & 24 & 8.8 \\
\hline & 4 times & 20 & 7.3 \\
\hline & 5 times & 26 & 9.5 \\
\hline & 6 times & 16 & 5.6 \\
\hline & 7 times & 22 & 8.1 \\
\hline & 8 times & 25 & 9.2 \\
\hline & 9 times & 24 & 8.8 \\
\hline & 10 times & 39 & 14.3 \\
\hline
\end{tabular}

In terms of m-banking application system usage, around half (47.3 percent) of the survey respondents stated that they performed more than five out of the last ten banking transactions (51 percent) on portable devices using downloadable m-banking applications, while approximately one fifth (18.3 percent) reported that they rarely used m-banking applications for banking transactions. When respondents recalled the last ten times they accessed wireless banking services, they reported using mobile applications for approximately half the sessions on average (mean $=5.29$ on a ten-point scale). The respondents' system usage is reflected in Table 1.

\section{DATA ANALYSIS AND RESULTS}

The hypotheses were tested with structural equation modeling (SEM) using partial least squares in SmartPLS 3.0 [32]. The measurement model had convergent validity, as factor loadings were all significant and greater than 0.70 and average variance extracted (AVE) for each latent construct was greater than the cutoff value of 0.50 [13, p.103]. Composite reliabilities were also high (all greater than 0.90), indicating acceptable internal reliability of the constructs. To test discriminant validity, we compared the square root of the AVE of each construct to the correlations of other latent variables. All the AVE square roots were larger than the correlations with any other two latent constructs (see Table 2).

Table 2. DiscriminantValidity Analysis

\begin{tabular}{|l|c|c|c|c|c|c|c|c|c|c|}
\hline & $(1)$ & $(2)$ & $(3)$ & $(4)$ & $(5)$ & $(6)$ & $(7)$ & $(8)$ & $(9)$ & $(10)$ \\
\hline User satisfaction (1) & $\mathbf{0 . 9 2 1}$ & & & & & & & & & \\
\hline System usage (2) & 0.573 & $\mathbf{0 . 9 6 7}$ & & & & & & & & \\
\hline Commitment (3) & 0.273 & 0.219 & $\mathbf{0 . 8 6 1}$ & & & & & & & \\
\hline Future intention (4) & 0.286 & 0.257 & 0.771 & $\mathbf{0 . 8 8 7}$ & & & & & & \\
\hline Overallsatifaction (5) & 0.292 & 0.184 & 0.702 & 0.702 & $\mathbf{0 . 9 4 1}$ & & & & & \\
\hline Recommend intention (6) & 0.217 & 0.116 & 0.645 & 0.623 & 0.684 & $\mathrm{n} / \mathrm{a}^{\mathrm{a}}$ & & & & \\
\hline Gender (7) & -0.188 & -0.198 & -0.169 & -0.216 & -0.120 & -0.165 & $\mathrm{n} / \mathrm{a}^{\mathrm{a}}$ & & & \\
\hline Age (8) & -0.118 & 0.024 & 0.095 & 0.004 & -0.035 & -0.072 & 0.098 & $\mathrm{n} / \mathrm{a}^{\mathrm{a}}$ & & \\
\hline Income (9) & -0.119 & 0.003 & -0.027 & -0.045 & -0.093 & -0.034 & 0.010 & 0.255 & $\mathrm{n} / \mathrm{a}^{\mathrm{a}}$ & \\
\hline Relationshipage (10) & -0.102 & 0.018 & 0.059 & -0.040 & -0.115 & -0.028 & 0.035 & 0.072 & 0.075 & $\mathrm{n} / \mathrm{a}^{\mathrm{a}}$ \\
\hline
\end{tabular}
be assessed.

The $R^{2}$ value for system usage (0.328) supports the model's predictive accuracy. The model's other $R^{2}$ values, commitment (0.081), intended future behavior (0.098), overall satisfaction $(0.061)$ and intention to recommend (0.039), were low.

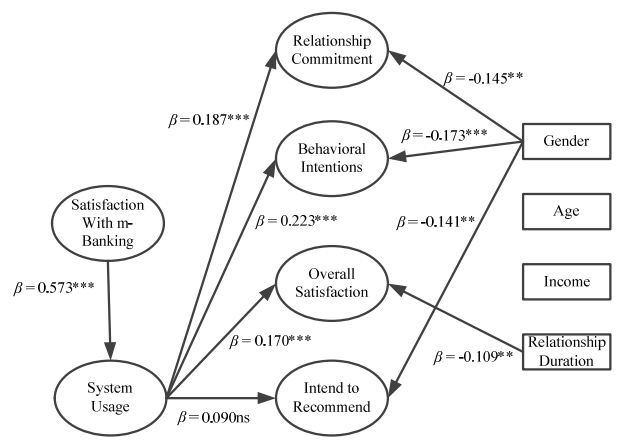

Notes: Only the significant paths of the control variables are shown; ${ }^{* *} p<0.01, * * p<0.05, \mathrm{~ns}=$ not significant

\section{Figure 2. Results of Hypothesis Testing}

Figure 2 depicts the results of the hypothesis testing. The significance and the strength of the path coefficients were examined when testing the six hypotheses. As seen in Figure 2, all path coefficients except one were significant at the $p<0.01$ level.

The results show that user satisfaction with an m-banking application has a strong positive association with usage $(\beta=$ 0.573 ) and that usage is positively associated with commitment $(\beta$ $=0.187)$, intended future behavior $(\beta=0.223)$, and overall 
satisfaction $(\beta=0.170)$. The effect of usage on intention to recommend was not significant $(\beta=0.090, \mathrm{~ns})$. Of the control variables, we found that gender is associated with commitment $(\beta$ $=-0.145, p<0.05)$, intended future behavior $(\beta=-0.173, p<0.01)$ and intention to $\operatorname{recommend}(\beta=-0.141, p<0.05)$ and that the duration of the banking relationship is negatively associated with overall satisfaction $(\beta=-0.109, p<0.05)$. The results indicate that women rate their commitment, future intentions and intention to recommend more positively than men do. In terms of relationship duration, the longer the relationship with the bank, the less likely customers are to give a high rating for overall satisfaction. This might indicate that in longer relationships factors other than affective motivations, like satisfaction, are reasons for staying in the relationship; these could include habitual behavior, for example [c.f. 43].

Although not hypothesized, we also examined the direct and indirect effects of user satisfaction with m-banking applications on the four outcome constructs by adding the user satisfaction relationships to those four outcome constructs (Figure 3).

This improved the $R^{2}$ values of commitment $(0.118)$, intended future behavior (0.122), overall satisfaction (0.106) and intention to recommend (0.065). Thus, linking user satisfaction of $\mathrm{m}$ banking applications to relationship outcomes clearly improved the predictive accuracy of the model. The effect of satisfaction with m-banking applications was strongest on overall satisfaction $(\beta=0.262, p<0.01)$ and commitment $(\beta=0.247, p<0.01)$. The effect was weaker, but also significant, on intention to recommend $(\beta=0.205, p<0.05)$ and intended future behavior $(\beta=0.193, p<$ $0.05)$.

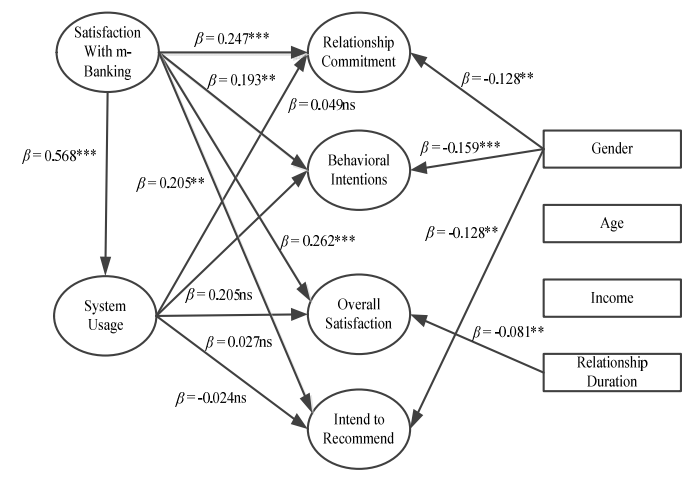

Notes: Only the significant paths of the control variables are shown; $* * * p<0.01, * * p<0.05$, ns $=$ not significant

Figure 3. Rival Model

In addition, we found that by adding these direct effects, the effects of system usage on the four outcome constructs were no longer significant for three relationships and became weaker for intended future behavior(commitment: $\beta=0.049$, ns; intended future behavior: $\beta=0.205, p<0.05$; overall satisfaction: $\beta=0.027$, $\mathrm{ns}$; and intention to recommend: $\beta=-0.024, \mathrm{~ns})$.

\section{DISCUSSION}

Information technology has inevitably brought about several

changes in customer-service relationships and banking service portfolios by modifying branch banking practices and introducing new and more innovative digital banking channels, including mbanking applications and services. Previous research [33] has investigated and identified a number of antecedents to and consequences of behavioral intentions to adopt and use m-banking services in developed, emerging and developing countries. The present study contributes to the literature on m-banking by providing a detailed and comprehensive understanding of $\mathrm{m}$ banking technology continuous usage in a developed country context.

The motivation of this empirical study was to examine the antecedents of consumers' continuous m-banking technology usage intention in Finland. In other words, this study aimed to extend our understanding of the relationship, outcomes and consequences of continuous usage of emerging banking information systems, i.e., m-banking applications. It is significant given that the behavioral intention to use $\mathrm{m}$-banking applications has largely been ignored by research in one way or another [1].

Overall, the results of our study support the validity of the developed theoretical model, which asserts that user satisfaction with $\mathrm{m}$-banking applications has a strong positive association with m-banking application usage, thus confirming H1. In addition, we found that system usage was positively related to bank-customer relationship development in terms of increased commitment to the bank (supporting H2), increased behavioral intention to stay with the bank (supporting H3), and increased overall satisfaction with the bank (supporting H4). No significant relationship was established between usage and intention to recommend (rejecting $\mathrm{H} 5$ ). This indicates that system usage is independent from a customer's intention to recommend the bank to others.

\subsection{Implications for Theory and Practice}

Some theoretical and managerial implications arise from this study. First, this study has developed additional insight into the theoretical foundation of m-banking usage by developing a comprehensive model to better understand m-banking applications and associated services offered on portable devices.

This study shows the importance of user satisfaction and system usage in strengthening bank-customer relationships. The results of this study show that system usage exerts the strongest influence on intended future behavior and commitment to the bank and is therefore vital for banks in forging a strong connection with customers.

Consumer satisfaction is crucial in different service industries, including financial services firms [21]; [6]. This study proposes that the impact of m-banking applications on the overall satisfaction of experienced users is increasing. Consequently, the financial services industry, including banks and microfinance institutions need to understand the factors underlying consumer expectations and enhance the continuous usage of their technologies, services and products such as by reducing costs as well as by thoroughly understanding the customer needs. In addition to increasing overall satisfaction, predicting and understanding system usage will help marketing executives determine what consumers are likely to do in the future after considering the fact that consumer attitude is increasingly fickle and more skeptical than ever before.

Perhaps more importantly, however, bank executives should also consider other factors when developing and deploying m-banking solutions. Here the need for collaboration with other industry players such as telecom sector and FinTech start-ups is crucial especially after considering the fact that banks are usually lagging behind in developing and deploying innovative technological platforms into their customer experience at the same pace at which customers are adopting these new technologies. Future collaborations with the non-banking sector will allow the banks to timely develop and provide value added services to new and existing consumer thereby increasing satisfaction and customer retention. 


\subsection{Limitations and Directions for Future Research}

The scope of m-banking is very broad, comprising various applications, channels, devices and methods for conducting $\mathrm{m}$ banking transactions. For instance, [33] have identified different points of access to m-banking, i.e., mobile applications that can be downloaded and used on a smartphone or tablet, mobile browsers that can be used with any mobile device or smartphone with a Web browser and short messaging services (SMS) that provide account notifications. One of the major limitations of this study is related to the usage of m-banking applications for conducting banking transactions. Future research could investigate other forms of m-banking such as m-payments and see if these services are similarly affected by the constructs used in this study.

A second limitation pertains to the scope of the study. This research was conducted in a single-country context (in this case Finland). Consequently, there are limitations to the generalizability of the findings. A few more studies (including comparative studies) across different regions, including developed, emerging and developing markets, is encouraged and recommended in order to generalize the research findings.

The third limitation relates to the duration of system usage. In prior research [e.g., 42], system usage has been examined in terms of three key conceptualizations: duration, frequency and intensity. This research specifically examined m-banking application usage duration and the share of one's banking conducting through $\mathrm{m}$ banking applications. Future research may consider all three measures of system use when examining m-banking services or applications and their effect on the determinants and outcome variables.

\section{REFERENCES}

[1] Al-Debei, M. M., Al-Lozi, E., and Papazafeiropoulou, A. 2013. Why people keep coming back to Facebook: Explaining and predicting continuance participation from an extended theory of planned behaviour perspective. Decision Support Systems. 55(1), 43-54.

[2] Anderson, E. W., and Sullivan, M. W. 1993. The antecedents and consequences of customer satisfaction for firms. Marketing Science. 12(2), 125-143.

[3] Böhmer, M., Hecht, B., Schöning, J., Krüger, A., and Bauer, G. 2011, August. Falling asleep with Angry Birds, Facebook and Kindle: a large scale study on mobile application usage. In Proceedings of the 13th International Conference on Human Computer Interaction with Mobile Devices and Services (Stockholm, Sweden, Aug 30-Sept 2, 2011).MobileHCI 2011, ACM New York, NY, USA, 47-56.

[4] Bokhari, R. H. 2005. The relationship between system usage and user satisfaction: a meta-analysis. Journal of Enterprise Information Management. 18(2), 211-234.

[5] Chen, S. 2012. To use or not to use: understanding the factors affecting continuance intention of mobile banking. International Journal of Mobile Communications. 10 (5), 490-507.

[6] Chung, N., and Kwon, S. J. 2009. Effect of trust level on mobile banking satisfaction: a multi-group analysis of information system success instruments. Behaviour \& Information Technology. 28(6), 549-562.

[7] De Wulf, K., Gaby, O-S., and Dawn, I. 2001. Investments in consumer relationships: A cross-country and cross-Industry exploration. Journal of Marketing. 65, 33-50.
[8] Dellarocas, C. 2003. The digitization of word of mouth: Promise and challenges of online feedback mechanisms. Management Science. 49 (10), 1407-1424.

[9] Federation of Finnish Financial Services, 2014. Säästäminen, luotonkäyttö ja maksutavat. Retrieved from http://www.fkl.fi/materiaalipankki/julkaisut /Julkaisut /Saastaminen_luotonkaytto_ja_maksutavat_2014.pdf. Retrieved on May 13, 2016.

[10] Gallup, T. N. S. 2012. Mobile life 2012. Retrieved from http://www.tnsglobal.com/mobile-life. Retrieved on June 1, 2016.

[11] Garbarino, E. and Johnson, M.S. 1999. The different roles of satisfaction, trust, and commitment in customer relationships. Journal of Marketing. 63, 70-87.

[12] Glasman, L. R., and Albarracín, D. 2006. Forming attitudes that predict future behavior: a meta-analysis of the attitudebehavior relation. Psychological Bulletin.132(5), 778.

[13] Hair, J.F.,Jr., Hult, G.T.M., Ringle, C.M. and Sarstedt, M. 2014. A Primer on Partial Least Squares Structural Equation Modeling (PLS-SEM). Thousand Oaks, CA: SAGE Publications.

[14] Heskett, J.L., Jones, T.O., Loveman, G.W., Sasser, W.E. and Schlesinger, L.A. 1994. Putting the service-profit chain to work. Harvard Business Review. March/April, 164-74.

[15] Howcroft, B., Hamilton, R., and Hewer, P. 2002. Consumer attitude and the usage and adoption of home-based banking in the United Kingdom. International Journal of Bank Marketing. 20(3), 111-121.

[16] Kang, H., Lee, M. J., and Lee, J. K. 2012. Are you still withus? A study of the post-adoption determinants of sustained use of mobile-banking services. Journal of Organizational Computing and Electronic Commerce. 22(2), 132-159.

[17] Karahanna, E., Straub, D.W., Chervany, N.L., 1999. Information technology adoption across time: a cross-sectional comparison of pre-adoption and post-adoption beliefs. MIS Quarterly. 23 (2), 183-213.

[18] Karjaluoto, H., Mattila, M., and Pento, T. 2002. Electronic banking in Finland: consumer beliefs and reactions to a new delivery channel. Journal of Financial Services Marketing. 6(4), 346-361.

[19] Kassim, N.M. and Abdullah, M.A.A. 2006. The influence of attraction on internet banking: an extension to the trustrelationship commitment model. International Journal of Bank Marketing. 24 (6), 424-42.

[20] Lee, I., Choi, B., Kim, J., and Hong, S. J. 2007. Culturetechnology fit: Effects of cultural characteristics on the postadoption beliefs of mobile Internet users. International Journal of Electronic Commerce. 11(4), 11-51.

[21] Lee, K. C., and Chung, N. 2009. Understanding factors affecting trust in and satisfaction with mobile banking in Korea: A modified DeLone and McLean's model perspective. Interacting With Computers. 21(5), 385-392.

[22] Lee, S., Kim, Y.R. and Lee, J. 1995. An empirical study of the relationships among end-user information systems: acceptance, training, and effectiveness. Journal of Management Information Systems. 12(2), 189-202.

[23] Li, H., and Liu, Y. 2014. Understanding post-adoption behaviors of e-service users in the context of online travel services. Information \& Management. 51(8), 1043-1052. 
[24] Liang, H., Saraf, N., Hu, Q., and Xue, Y. 2007. Assimilation of Enterprise Systems: The Effect of Institutional Pressures and the Mediating Role of Top Management. MIS Quarterly. 31 (1), 59-87.

[25] Limayem, M., Hirt, S. G., and Cheung, C. M. 2007. How habit limits the predictive power of intention: The case of information systems continuance. MIS Quarterly. 31(4), 705-737.

[26] Lin, H.-H., and Wang, Y.S. 2006. An examination of the determinants of customer loyalty in mobile commerce contexts. Information \& Management. 43 (3), 271-282.

[27] Locke, E. A. 1979. The Nature and Causes of Job Satisfaction. In Handbook of Industrial and Organizational Psychology, M. D. Dunnette (ed.), Holt, Reinhart and Winston, New York, 1976, 1297-1349.

[28] Montoya-Weiss, M. M., Voss, G. B., and Grewal, D. 2003. Determinants of online channel use and overall satisfaction with a relational, multichannel service provider. Journal of the Academy of Marketing Science. 31(4), 448-458.

[29] Oliveira, T., Thomas, M., Baptista, G., and Campos, F. 2016. Mobile payment: Understanding the determinants of customer adoption and intention to recommend the technology. Computers in Human Behavior. 61, 404-414.

[30] Ouellette, J. A., and Wood, W. 1998. Habit and intention in everyday life: the multiple processes by which past behavior predicts future behavior. Psychological Bulletin. 124(1), 54.

[31] Reichheld, F., and Markey, R. 2011. The ultimate question 2.0: How net promoter companies thrive in a customer-driven world. Boston, MA: Harvard Business Review Press.

[32] Ringle, C.M., Wende, S. and Becker, J.M. 2014. SmartPLS 3. Retrieved from http://www.smartpls.com.Retrieved on November $1,2015$.

[33] Shaikh, A. A., and Karjaluoto, H. (2015). Mobile banking adoption: A literature review. Telematics and Informatics. 32(1), 129-142.

[34] Shaikh, A. A., Karjaluoto, H., and Chinje, N. B. 2015 a. Continuous mobile banking usage and relationship commitmentA multi-country assessment. Journal of Financial Services Marketing. 20(3), 208-219.

[35] Shaikh, A. A., Karjaluoto, H., and Chinje, N. B. 2015 b. Consumers' perceptions of mobile banking continuous usage in Finland and South Africa. International Journal of Electronic Finance, 8(2-4), 149-168.

[36] Söderlund, M., and Mattsson, J. 2015. Merely asking the customer to recommend has an impact on word-of-mouth activity. Journal of Retailing and Consumer Services. 27, 80-89.

[37] Statistics Finland (2014). Väestön tieto- ja viestintätekniikan käyttö [verkkojulkaisu]. Retrieved from http://www.stat.fi/til/sutivi/index.html.Retrieved on May 13, 2015.

[38] Straub, D., Boudreau, M.-C., and Gefen, D. 2004. Validation guidelines for IS positivist research. Communications of AIS. 13, 380-427.

[39] Sweeney, A. andMorrison,M. (2003) Clicks vs. bricks:Internet-facilitated relationships in financial services. International Journal of Internet Marketing and Advertising. 1(4), 350-370.
[40] The World Bank, 2009. The infinite potential of mobile banking. Retrieved from htpp://psdblog.worldbank .org/psdblog/2009/11/the-infinite-potential-of-mobile-banking. Retrieved on June 1, 2016.

[41] Trice, A.W. and Treacy, M.E. 1988. Utilization as a dependent variable in MIS research. Data Base, 33-41.

[42] Venkatesh, V., Brown, S. A., Maruping, L. M., and Bala, H. 2008. Predicting different conceptualizations of system use: the competing roles of behavioral intention, facilitating conditions, and behavioral expectation. MIS Quarterly. 32(3), 483-502.

[43] Venkatesh, V., Thong, J. Y., and Xu, X. 2012. Consumer acceptance and use of information technology: extending the unified theory of acceptance and use of technology. MIS Quarterly. 36 (1), 157-178.

[44] Warshaw, P. R., and Davis, F. D. 1985. Disentangling behavioral intention and behavioral expectation. Journal of Experimental Social Psychology. 21(3), 213-228.

[45] Zhou, T. 2013. An empirical examination of continuance intention of mobile payment services. Decision Support Systems. 54(2), 1085-1091.

\section{Appendix}

User satisfaction with the m-banking (MB) application (CR = 0.957; $\mathrm{AVE}=0.848$ )

- I think I made the correct decision to use the MB application.

- I am satisfied with the way that the MB application carries out my transactions.

- I am satisfied with the service I receive from MB application.

- Overall, I am satisfied with the MB application.

System usage $(\mathrm{CR}=0.966$; $\mathrm{AVE}=\mathbf{0 . 9 3 4})$

- Please estimate how much of your banking (as a percentage) is conducted via an MB application.

- Recalling the last ten times you logged into wireless banking services, how many times did this involve an MB application?

Overall satisfaction with the bank $(\mathrm{CR}=0.939$; $\mathrm{AVE}=\mathbf{0 . 8 8 5})$

- How would you rate your overall satisfaction with your current bank?

- How would you rate your overall satisfaction with your current bank compared with other banks?

Commitment to the bank $(C R=0.920 ; A V E=0.742)$

- I am proud to be a customer of my current bank.

- I feel a sense of belonging to my current bank.

- I care about the long-term success of my current bank.

- I am a loyal patron of my current bank.

Intention to stay with the bank in the future $(C R=0.916$;

AVE $=0.787$ )

- I plan to continue as a customer with my current bank.

- I plan to stay with my current bank in the future.

- I am considering expanding my banking affairs with my current bank.

Intention to recommend the bank (Net Promoter Score)

- How likely are you to recommend your current bank to other people 